\title{
RECEPTION THEORY AND THE CHRISTIAN READER: A PRELIMINARY PERSPECTIVE
}

\author{
A.L. Combrink, Department of English, PU for CHE
}

\begin{abstract}
In recent years there has been a significant shift in emphasis trom textcentred criticism in literature to reader-centred criticism. This new field of criticism, called Reception Theory or Reader Response Criticism, denies the immulable nature of the "text" and regards as its object of study the work of literature that is created through the co-constituent creative and interpretive acts of both writer and reader.
\end{abstract}

Some theoretical background is given to this approach and its significance in drama studies is indicated. In the final section an indication is given of the application of this approach to the Christian reader by way of reference to Fugard's most recent play Master Harold . . and the Boys.

\section{INTRODUCTION}

Terry Eagleton, in his very recent work I iterary Theory (1983) says that "Reception theory examines the reader's role in literature, and as such is a fairly novel development. Indeed, one might very roughly periodize the history of modern literary theory in three stages: a preoccupation with the author (Romanticism and the nineteenth century): and exclusive concern with the text (New Criticism): and a marked shift of altention to the reader over recent years. The reader has always been the most underprivileged of this trio strangely, since without him or her there would be no literary texts at all. Literary texts do not exist on bookshelves: they are processes of signification materialized only in the practice of reading. For literature to happen, the reader is quite as vital as the author" (p. 74).

For the past forty years the so-called New Criticism or formalist criticism has been regarded as the most respectable form of literary criticism by the more fastidious of the literary theoreticians. The object of study of the New Critics has been largely poetry, and because of the very nature of poetry it has been possible to postulate that the objert of scrutiny for the critic, the poem, has an inviolate and immutable existence, not subject to change by other varying conditions. This is precisely the attitude that is being challenged at present in the signilicant upsurge or critical work on Reception Theory (Reception Aesthetics), a field at present led largely by the German critic of Konstanz, Wolfgang Iser. It is a form of literary criticism that is seen to have derived most prominently from phenomenology and hermeneutics, especially the

Koers, 48(2) 1983 
work of Husserl and Gadamer. By its very novelty the validity and the applicability of this approach will still be open to many weaknesses and problems, but in the field of drama (studied in both its literary and theatrical manifest ations) it does offer very valuable critical tools and insights. Some of these will be outlined and discussed briefly in the theoretical discussion before an actual discussion of a play will be provided to illustrate some of the possibilities of this approach.

\section{SOME THEORETICAL CONCEPTS OF THIS APPROACH}

In Reception Theory the concern is very much with three main components of the literary event: the writer, the "text" and the reader (or, in the case of the theatre, the audience - one can thus perhaps more correctly speak of the receptor). Various critics accord different degress of importance to the different components, and depending on the nature of the work in question, the relative importance of each may vary significantly. According to Marianne de long (Standpunte 164, p. 48) this difference in emphasis can result in many reductionist practices: the literary work might be reduced to the stature of a mere instigator, or it might be elevated to the stature of manipulator - and either the work or the reader can be degraded to the level of being empty objects to the supplemented, filledin by the other, without any dynamic co-operative work taking place.

\section{THE AUTHOR}

In any encounter which ultimately becomes literature (in Reception Theoretical terms) the first element, the instigator or initiator is the author, who becomes in the process of interaction the implied author, defined in the following terms: It is a manipulating, controlling power, the embodiment or the source of values portrayed in the work, as well as the organizer or manipulator in the narrative process or narrative discourse aimed at reaching the implicit reader. Generally speaking, the implied author may be more clearly delineated from the position of the artefact which results from his originating work than the implied reader, which is much more variable entity. The supposition is that reader and author meet each other creatively. According to Steenberg (1983, p. 57) there should be sufficient similarity of cultural and value systems between the two entities to render communication possible: With reference to the novel Houd-den-Bek by André P. Brink, Steenberg feels that the following qualities should be shared by them at the very least (the implied reader should also have these qualities which are held by the author):

- he should know Afrikaans thoroughly (this statement is relativized to some 


\section{Combrink}

extent by the fact that there is also an English version of this novel translated by the author himself):

- he should know the Bible and Christian values and norms well enough to be able to understand the nuances of falsification of Scriptural truths by the personages in the novel (this statement is relativized to some extend by explicit statements by the real author that he also writes for non-Christians):

- he should know the racial problem in this country (this statement is relativized by the universality of the problem of racial tension):

- he should be able to identify with the main figure in the novel - which would not be all that easy for a large number of readers in the South African context, as the attitudes held by the main figure are essentially against the political status quo. (This is also a problem in the play by Fugard to be discussed later, but in that case identification with the main figure is easier, because the problem under discussion does not touch on the politically oversensitive issue of miscegenation - rather it remains centred on the universal problem of love and caring, and thus evades the too sensitive issue louched upon in the Brink work.)

In works of committed literature, expecially, the implied author emerges strongly as manipulator and not merely, as seen in terms of this approach to criticism, as co-structuring agent, and this manipulative action might account to some extent for the negative awareness the reader develops at times upon being subjected to a too-sustained propagandistic altack under the guise of literature, when the development of an active aversion negates any chance of a real encounter in terms of "literary experience",

\section{THE “TEXT”}

This is perhaps the most debated entity in this framework of literary co-existence. One of the most provocative works in this context is the seminal work by Stanley Fish (1982): Is There a Text in this Class? Fish himself, in his Preface, comments on it in the following way: "The answer this book gives to its title question is 'there is and there isn't". There isn't a text in this or any other class in one ineans by text what E.D. Hirsch and others mean by it, "an entity which always remains the same from one moment to the next' (Validity in Interpreta(ion, p. 46): but there is a text in this and every class if one means by text the structure of meaning that is obvious and inescapable from the perspective of whatever interpretive assumptions happen to be in force" (p. vii). There are various important points here which will be illuminated again later, notably his concept of "interpretive assumptions", seen in the light of the fact that the 


\section{Reception Theory and Chrislian reader}

\section{sub-title of his book is The Authority of Interpretive Communities.}

Whereas some degree of variation is to be discerned among various critic on this issue, it is important to note that there is seemingly strong consensus on the fact that there is no autonomous text. The "text" does not have a closed and constant mode of existence. In the view of Iser (critically and evaluatively presented by Marianne de Jong in two consecutive issues of Standpunte [164 and 165] ), the text is seen to contain the reader, in the shape of possiblilities of meaning, being in Eagleton's terms a series of cues to the reader, and the reader is then supposed to actualize this text by formulating the meanings. The "literary message" is to be seen as a "reading instruction" - it is not meaning, it is an instruction lowards the formation of meaning by the reader. The reader is then co-constituent of the contexts created by the text. The text is seen as having a repertoire, and this repertoire consists of the selected elements of reality, a framework of known quantities which gives the reader access to the veiled meaning. The text is seen, expecially in the modern novel and in modern drama, to contain many points of hiatus - Iser refers to "Leerstelle": empty spaces to be filled in by the co-constituing actions of implicit reader or receptor. In drama specifically, where in modern plays the question of "subtext" has become a most important theoretical consideration, this has to be looked at carefully (in this respect the points of correspondence between implied author and implied reader as outlined by Steenberg should be kept in mind carefully - also with regard to the play to be discussed in the second part of this article). It is also felt that the work forces the reader to maturity in this way, for the more seemingly opaque the work of literature, the more hiatus-filled, the more independent interpretation is demanded of the reader, and the more he is forced to alter his horizon by filling it in with previously unmet and unabsorbed information.

\section{THE READER (RECEPTOR)}

This is at present regarded by some critics as being the most important of the elements of the literary experience. One is immediately confronted, however, with a number of very real problems, because "the reader" is at best a very contingent and tenuous concept, and to be acceptable in terms of "critical respectability" this concept has to be carefully evaluated and given shape. What cannot be denied, especially in a study of drama (both in terms of literature and of theatre) is that "reception" is a reality and should be dealt with in a purposeful manner.

The reader is seen, as has already begun to emerge, as co-creator, thus also text-implied and textually anchored. The idea is to search for a method to 


\section{Combrink}

render the variable reader - the ordinary individual as reader, the critic or lecturer in literature as reader, the literary theoretician as reader - descriptive together with the text. Interpretation is then to be regarded as the interplay between fixed text and variable reader. In drama there would be even mure variables as there are so many purely theatrical considerations linked to the variable receptor - not one of which can really be denied significance in terms of the total experience.

The reader (for this, always read "variable reader") concretizes the literary work, which is "in itself no more than a chain of organized black marks on a page" (Eagleton, p. 76).

In order to actualize the literary work, which is seen as always being a dynamic process, "a complex movement and unfolding through time" (p. 77), the reader will bring to the work certain "pre-understandings", a dim context of beliefs and expectations within which the work's various features will be assessed. Depending on his own horizon* the reader will select and organize its elements, "excluding some and foregrounding others" (p. 77). Eagleton persuasively argues that "reading is not a straightforward linear movement, a merely cumulative affair: our initial speculations generate a frame of reference within which to interpret what comes next, but what comes next may retrospectively transform our original understanding, highlighting some leatures of it and backgrounding others" (p. 77).

This brings one to the question of the recognition of "codes" by the reader these codes can be described as elements of reality, and their recognition, according to De Jong (164, p. 52) is accompanied by a recognition of halfhidden and possibly repressed aspects by the reader within himself and his reality. Eagleton feels that the work "interrogates and transforms the implicit beliefs we bring to it, 'disconfirms' our routine habits of perception and so forces us to acknowledge them for the first time for what they are" (p. 79). He feels that the valuable work of literature "violates or transgresses these normative ways of seeing, and so teaches us new codes for understanding" (p. 79). (This idea is of great importance for the discussion of the Fugard play, Master Harold . . . and the Boys, which will be discussed in the second half, especially when seen in conjunction with some of the overtly existentialist plays of this country.)

\footnotetext{
- The equivalent of the textual repertoire is thercfore the horizon of the reder: his literary
} competence, his experiential world, his political altiludes, knowledge, etc. 
All these considerations still revolve around the idea of the variable reader. In order to render the variable reader less amorphous, arbitrary, contingent and slippery - to name but a few of the reservations voice by antipathetic critics - one can think of the implied reader in any literary experience as being part of a reading community, as being a sharer of certain assumptions, certain fixed conventions with regard 10 literature and literary expectations. Most critics go along with the idea that, because a work is not read, received, apprehended in a void, it implies that readers/receptors are socially and historically positioned, and "how they interpret literary works will be deeply shaped by this fac" (Eagleton, p. 83). There is always the indisputable fact that a literary text is implicitly aimed at a certain potential audience, and is expected to be read/received/apprehended by that same audience. An author cannot really be said to write with a sublime sense of indifference to the possible/probable/inevitable readers of his text: the mere fact of publication, in fact, presupposes an awareness of a receptor of whatever nature. The responses this implied reader would have will be shaped by the slock of socially legitimated ways of reading works, by the shared assumptions, by the sharing of readerly conventions. This brings us to Fish's definition of the role of interpretive communities:

Interpretive communities are made up of those who shar e interpretive strategies not for reading but for writing texts, for constituting their properties. In other words, these strategies exist prior to the act of reading and therefore determine the shape of what is read rather than, as is usually assumed, the other way around.

(1982, p. 14).

The whole issue of the validity of the reading by one reader as opposed to the reading by another reader will have to be closely scrutinized wit hin the framework of this theory. It is felt that it is an academist delusion to see the literary work as an arena of endless and infinite possibility of interpretation. The implied reader in each case, together with his stock of assumptions which he shares with other readers of his reading community (which is not a geographical community) will have to be pinpointed further. This is done in some ways in a purely empirical fashion, through surveys of readers, where random samples from the reading public are drawn and their responses determined by means of questionnaires and other practical strategies. This is, however, a cumbersome process, which would at this stage seem to have a confirmatory rather than any other function.

\section{THE IMPLIED READER, IDEOLOGY AND INTERPRETATION}

Eagleton, in discussing Iser's reception theory, says that it is "based on a liberal humanist ideology: a belief that in reading we should be flexible and openminded, prepared to put our beliefs into question and allow them to be trans- 


\section{Combrink}

formed. Behind this case lies the influence of Gadamerian hermeneutics*, with its trust that the enriched self-knowledge which springs from an encounter with the unfamiliar. But Iser's liberal humanism, like most such doctrines, is less liberal than it looks at first sight. He writes that a reader with strong ideological commitments is likely to be an inadequate one, since he or she is less likely to be open to the transformative power of literary works. What this implies is that in order to undergo transformation at the hands of the text, we must only hold our beliefs fairly provisionally in the first place. The only good reader would already have to be a liberal: the act of reading produces a kind of human subject which it also presupposes" (p. 79).

This is an important issue, for in dedling, for example, with the Christian reader, one would have to keep in mind that the Christian reader has an "ideological" bias in reading. What Iser is afraid of, however, is not so much, to my mind, the ideological reader, or in this case the Christian redder, but the prejudiced reader, and prejudice, aimed at whatever issue, cannot render a good reading. It is true that the reader, when he comes to a reading or literary (interpretative) situation is already largely shaped, already has a firm and fixed personality, and as such is not really all that open to change by means of a reading interaction. What is important, however, is to keep in mind that it is not the fact that the reader might hold to specific beliefs (whether they be religious or ideological in the Marxist sense) but that he might be so blinded by prejudice that he might be a less than open reader, only partially re-creating then the potential literary work initiated by the author.

\section{A DISCUSSION OF MASTER HAROLD . . AND THE BOYS (FUGARD)}

The play will be discussed by way of two possible readings: first, the obvious implied political reading by a South African audience, and secondly, a reading based on a Christian lifeview.

The play, which has an openly confessional basis (Fugard in a programme note tells about the painful episode in his boyhood years which finally prompted the writing of this playl is a striking comment on a variety of issues. The intense shame which sprang from his despicable if understandable act prompted the writing - which can be seen to have been intended as a cathartic act. It also raises interesting issues about the validity of creating

- Pect van Kensburg, in an arlicle on Lifeview on Perception of Message in Drama (Koers, 1981, 164) discusses this in delail, commenting illuminatingly on the issue of horizon in the perceptor. 


\section{Receplion Theory and Christian reader}

a play so faithfully as a confession - the interesting point is that it seems to engage the receptor even more closely.

Briefly, the play involves an afternoon in the lives of the main character, Hally (Master Harold), the son of the female café owner in Port Elizabeth who employs two black men, Sam, the waiter, an intelligent and articulate black man who has become a father-surrogate to Hally (Hally's father is an unrehabilitated alcoholic), and his simpler friend, Willy, who cleans. Hally's father is released from hospital entirely unexpectedly and Hally is dumped into a crisis. He does love his father, but the relationship is so ambivalent that he cannot even begin to understand it. Sam does, and tries to resolve the situation, succeeding only in infuriating the tense and unhappy boy who has to come to terms with his own feeling. When Hally becomes really cornered by the situation, he turns on Sam, in what might be seen by an adult as a cry for help - and to a large extent and for a long time Sam is able 10 handle it in that way. Yet the actual harsh political siluation intrudes. Ilally, in a final burst of anger, directed at the world but hitting Sam, indulges in a crude joke (His father's favourite) about the colour of a sensitive part of the anatomy of a black man. Sam is incredulous at this, and at this point the racial tension intrudes and Sam, in a moment unequalled for dramatic tension, drops his trousers and presents his anatomy for inspection. He is ashamed later of his intolerence towards a child, but at the moment of the act, his behaviour seems entirely acceptable, even inevitable. Hally's shame is compounded many times over by this dastardly act, but he is unable to retract, and in an access of uncontrollable emotion, he spits in Sam's face, almosi prompting Sam to assault him. The ending of the play is left open - Hally (who now insists on being called Master Harold, breaking the intimacy of the past) leaves but might return, Sam tries quictly to return to the dream world of dancing contests which has for so long sustained him. The openness of the ending provides all the opportunity of the world for interpretative creation by the receptor, and this is in fact what happens in this play and in other modern plays.

the implications for reading or viewing perception of this play are obvious. It is highly significant, in view of the authobiographical nature of the work, that Fugard should have chosen (unlike the case had been with his other works) to have had it performed, for the première, outside South Africa. The interpretive community in South Africa would have been, to his mind, too "loaded" in terms of attitudes and feelings to have viewed it in a way which would have given him a clear indication as to the value of the work. He himself says that he wanted to "validate its universality" outside the country. 


\section{Combrink}

\section{THE PLAY AND ITS IMPLIED INTERPRETIVE COMMUNITY}

The? main bias which would inevitably be held in this play is the matter of political awar eness. The centre of the play is about love - love in many manifestaticns but essentially the love between child and father, father-surrogate, and vice versa. Cast as it is against the unfortunate background of the racial situation in South Africa it gains tremendously in ironic potential, although the danger of undue manipulation by the implied author is there, especially in the last part of the play, following the climatic events outlined in the synopsis of the play provided above: the author rather too explicitly "Ieans" on the receptor to make clear some of his ideas which could have been derived with fair accuracy by the kind of informed receptor who would constitute part of the fairly small and homgeneous thedtre population of South Africa. The play does, however, undoubledly engage the receptor and sets in motion the process by which the repertoire of the play begins to interact with the horizon of the receptor(s): and in the inplied audience in South Africa different plays will emerge. Primarily, on the basis of information about the playgoing habits of South Africans, an assumption may be made about the main body of play. goers, who will mostly be white South Africans of more than one language group and more than one political persuasion. In view of the overtly political appeal in dealing with the Black/White issue, the author will engage the audience differenlly. The minority group of Black viewers will probably be engaged in lerms of strong identification with the hurt emanating from the waiter-figure. The more "left-wing" among the audience will be at once and passionately (even militantly) aware of injustice and the crying need for elimination of restrictive legislation which so erodes human relationships. The interactive process should be less ambivalent than is the case for the more "right-wing" receptor, leaving this latter receptor more scope for interaction with a view to maturation. For the more politically conservative receptor, there is a more shattering involvement. The appeal of the play is such that one is drawn into it against preconceived notions and prejudices: the more conservative receptor (although, let it be said, not a violently biased receptor, who will merely become aggressive) will be pulled into the play violently and will, in terms of the Iserian model, be expected constantly to match his horizon (inadequate in terms of the appeal being made to it) to the repertoire of the play, and to modify his responses constantly and imaginatively, to render ultimately, through creative co-operation with the author, a "play" which will approximate that of the left-wing receptor to a greater extent than before, and which will then also make possible a larger area of consensus, or universal appeal. 


\section{Reception Theory and Christian reader}

\section{THE CHRISTIAN READER OF THIS PLAY}

When one comes to the Christian reader of this play (or any other play for that matter) a vexed question is raised again. The term Christian reader has nol yet been satisfactorily defined. For the purposes of this brief discussion, the idea should be held that the Christian reader is the rearler who professes to hold a Christian world view, and who would then of necessity try to account for the effect of this world view in the interpretative actions in which he might indulge.

It would seem at this stage as if Reception Theory might provide a valuable set of insights for the whole matter of the discussion of literary criticism from a Christian point of view. When the reader (of what ever persuasion) is brought into contact with the text (of whatever kind) the interpretative co-constituent act brings together the repertoire of the text and the horizon of the reader. When there is a close match between horizon and textual repertoire, the interpretation can be a complete one and can match in all respects. In this play, for example, the central ethic that is expressed, the love ethic which might prevail in spite of all other impediments, brings about a match between the repertoire and the horizon of the Christian receptor, so that the receptor may easily and without undue conflict assimilate this textual content. There will also be a match with other interpreters: the humanist will find this ethic as easy to identify with and will therefore as easily go along with it. There will be, therefore, a fair amount of overlap when it comes to the "interpretive community" at work here. The smaller elements which might not be part of the overlap will be peripheral concerns and will not materially influence the total interpretative action. Thus, when the strategy of the author - in this case the employment of the love ethic as a major thematic concern - forces a similarity of interpretation, a larger area of consensus may be reached.

Something entirely different, however, happens when the Christian reader faces a play which professes a completely alien world view. In Beckett's Waiting for Godot, for example, the existentialist world view is at odds with the world view professed by the reader who holds a Christian view - but the reader is still drawn into and involved in the play because it deals compellingly with human problems peculiar to our time and to our world. What happens now to the reader?

In a case like this, it would seem, there is even more possibility of interactive creation, for the lack of "matching" between repertoire and horizon in this case creates a greater amount of tension and also demands of the receptor a far greater amount of creative adaptation and adjustment. Fe need not 


\section{Combrink}

change his world view to adapt to another world view, but in what he experiences in the course of the receptive action, he enlarges his own horizon, he enriches himself significantly, and he even strengthens his own beliefs... for the truly open-minded Christian reader will not be blinded by cheap prejudice to disregard elements in the work, to express moralistic views in the mislaken belief that they are literary judgements. When the truly open, creative interaction has taken place, the work which comes into being through the act of reading by the Christian reader will differ only in the perhaps stronger tension created by the unresolved stresses between horizon and repertoire, and which can only really give rise to further and fruitful creative interaction.

\section{REFERENCES:}

DE JONG, Marianne. 1983. Die blootgestelde leser: Wolfgang Iser se model (I en II) Standpunte, 164, 165.

STEENBERG, D.H. 1983. Die manipulerende vol van die implisiete outeur. Bloemfontein, SAVAL-Kongresreferate.

EAGLETON, T. 1983. Literary Theory. London, Blackwell.

FISH, S. 1982. Is there a text in this class? Harvard University.

IUGARD, A. 1982 Master Harold ... and the boys. Oxford University Press. 